\title{
Penggunaan Media Sosial Facebook Bagi Remaja Laki-Laki Dalam Menjalin Hubungan Pacaran
}

\author{
Use Of Facebook Social Media For Boys In Establishing Dating Relationships
}

\author{
Haris Muhammad ${ }^{1}$, Irwansyah ${ }^{2}$ \\ Pascasarjana Ilmu Komunikasi, Fakultas Ilmu Sosial dan Ilmu Politik, \\ Universitas Indonesia, Jl. Salemba Raya No. 4, Jakarta, Indonesia 10430 \\ Email: haris.muhammad01@ui.ac.id ${ }^{1}$,irwansyah09@ui.ac.id ${ }^{2}$
}

\begin{abstract}
ABSTRAK
Studi ini membahas mengenai penggunaan media sosial Facebook bagi remaja laki-laki dalam menjalin hubungan pacaran. Teori utama yang digunakan yaitu Teori Pengurangan Ketidakpastian terkait konsep interaksi awal ketika pertemuan antar individu. Dalam teori pengurangan ketidakpastian, terdapat tiga alasan bahwa seseorang akan meningkatkan perhatian yang diberikan pada tindakan orang lain, yakni: insentif, penyimpangan, dan interaksi di masa depan. Poin pertama adalah ketika seseorang mengharapkan bahwa orang lain akan memberikan informasi yang berguna atau bentuk penghargaan lainnya. Poin kedua terjadi ketika seseorang bertindak dengan cara yang menyimpang. Terakhir, kemungkinan interaksi di masa depan dengan orang lain juga meningkatkan seberapa dekat kita memantau perilaku mereka untuk mengurangi ketidakpastian. Teori Pengurangan Ketidakpastian dipilih karena merupakan teori yang dapat diimplementasikan ketika telah terjadi interaksi awal dengan orang lain yang dipandu oleh komunikasi antar individu. Pendekatan kualitatif bersifat eksploratif yang dipakai dalam studi ini dan metodologi yang digunakan melalui wawancara mendalam. Hasil dari penelitian ini menyimpulkan bahwa teori pengurangan ketidakpastian merupakan kerangka teoritis yang tepat untuk memahami peran Facebook dalam hubungan asmara remaja. Hal ini menunjukkan pengurangan ketidakpastian aktif dikaitkan dengan strategi pengurangan ketidakpastian pasif dalam hubungan romantis seperti pemantauan online, sepenuhnya sesuai dengan rumusan teori pengurangan ketidakpastian.
\end{abstract}

Kata Kunci: Media Sosial, Facebook, Teori Pengurangan Ketidakpastian, Hubungan Pacaran.

\begin{abstract}
This study discusses the use of social media Facebook for teenage boys in dating relationships. The main theory used is Uncertainty Reduction Theory related to the concept of early interactions when encounters between individuals. In the uncertainty reduction theory, there are three reasons that a person will increase the attention paid to the actions of others, namely: incentives, deviations, and future interactions. The first point is when someone expects that other people will provide useful information or some other form of appreciation. The second point occurs when a person acts in a deviant way. Lastly, the likelihood of future interactions
\end{abstract}


with other people also increases how closely we monitor their behavior to reduce uncertainty. Uncertainty Reduction Theory was chosen because it is a theory that can be implemented when there has been an initial interaction with other people which is guided by communication between individuals. The qualitative exploratory approach used in this study and the methodology used through in-depth interviews. The results of this study conclude that the uncertainty reduction theory is an appropriate theoretical framework for understanding Facebook's role in adolescent romance. This suggests that active uncertainty reduction is associated with passive uncertainty reduction strategies in romantic relationships such as online monitoring, fully in line with the uncertainty reduction theory formulation.

\section{Keywords: Social Media, Facebook, Uncertainty Reduction Theory, Dating} Relationships

\section{PENDAHULUAN}

Hubungan romantis dibangun dan ditantang oleh teknologi komunikasi yang muncul (Bryant \& Marmo, 2009; Utz \& Beukeboom, 2011). Misalnya, kecemburuan dapat terjadi di antara pasangan jika ketidakpastian muncul sebagai akibat dari pengamatan perilaku online (Bevan, 2004). Penggunaan Facebook di kalangan remaja di perguruan tinggi dan indikasi bahwa pemeliharaan hubungan relasional adalah motif penggunaan Facebook menyebabkan para mahasiswa mulai mengeksplorasi efek penggunaan situs jejaring sosial (Social Network Service) tentang pemeliharaan hubungan romantis (Bryant \& Marmo, 2009; Ellison, Steinfield, \& Lampe, 2007; Utz \& Beukeboom, 2011). Facebook adalah situs jejaring sosial yang memungkinkan penggunanya membuat profil online untuk menampilkan identitas dan minat mereka di forum publik, mengungkapkan informasi pribadi, dan terhubung dengan pengguna lain (Bryant \& Marmo, 2009) . Saat ini, ada lebih dari satu miliar pengguna Facebook (Facebook.com, 2012). Ellison dkk. (2007) mengungkapkan bahwa 20\% dari peserta usia kuliah menghabiskan lebih dari satu jam di situs Facebook setiap hari dan hampir 90\% dari peserta remaja melaporkan memposting status hubungan mereka di Facebook untuk tampilan publik. Prevalensi Facebook mengubah lanskap relasional, dalam hal ini memberikan kesempatan untuk pengawasan oleh pasangan (Bryant \& Marmo, 2009). Penyebaran situs jejaring sosial dapat dibandingkan dengan jaringan sosial perorangan tradisional sebagai sumber pengurangan ketidakpastian (Westerman, 2008). Seperti yang diakui Walther (1996), kurangnya isyarat kontekstual online dapat menciptakan ketidakpastian atau memicu kecemburuan 
saat menggunakan situs jejaring sosial untuk berkomunikasi dalam hubungan romantis. Mengingat kemungkinan bahwa situs jejaring sosial mungkin dikaitkan dengan ketidakpastian, penelitian ini melibatkan Uncertainty Reduction Theory (URT). Menurut aksioma URT, ada hubungan positif antara pencarian informasi dan ketidakpastian. URT menunjukkan bahwa pasangan memanfaatkan perilaku komunikatif dalam upaya mengurangi ketidakpastian (Berger \& Calabrese, 1975). Dengan demikian, situs jejaring sosial seperti Facebook dapat digunakan untuk berkomunikasi dan memperoleh informasi tentang pasangan.

Penelitian sebelumnya mendukung penelitian teoritis ini, Parks dan Adelman (1983) meneliti URT dalam konteks hubungan kencan, menemukan bahwa jaringan sosial mitra (yaitu, keluarga dan teman pasangan) berfungsi sebagai sumber untuk pengurangan ketidakpastian dan menyediakan stabilitas relasional. Sebaliknya, Muise, Christofides, dan Desmarais (2009) mengakui bahwa peningkatan waktu menggunakan Facebook dapat memprediksi kecemburuan terkait Facebook. Dengan demikian, Facebook dapat menghasilkan komplikasi pada norma pemeliharaan dan menghadirkan tantangan bagi mitra karena potensi risiko menciptakan ketidakpastian melalui interaksi online (Donath \& Boyd, 2004; Spitzberg \& Hoobler, 2002). Penelitian dari Michael G. Blight, Erin K. Ruppel \& Kristy Jagiello (2019), "Using Facebook Lets Me Know What He is Doing:" Relational Uncertainty, Breakups, and Renewals in On-again/Off-again Relationships menyelidiki perilaku yang mengurangi ketidakpastian baik secara umum maupun di media sosial Facebook. Pengguna Facebook usia remaja menanggapi langkah-langkah ketidakpastian relasional tertutup dan jumlah perpisahan dan rujuk kembali, dan pertanyaan terbuka mengenai alasan perpisahan / rujuk kembali dan strategi pengurangan ketidakpastian relasional. Ketidakpastian hubungan lebih tinggi di antara peserta tahap "putus" dan mereka yang melaporkan jumlah putus yang lebih tinggi.

Jesse Fox, $\mathrm{PhD}$, and Courtney Anderegg, MA dalam studinya Romantic Relationship Stages and Social Networking Sites:Uncertainty Reduction Strategies and Perceived Relational Norms on Facebook, meneliti bagaimana situs jejaring sosial digunakan untuk mencari informasi tentang pasangan romantis potensial atau saat ini. Hasil menunjukkan bahwa seiring kemajuan hubungan, norma yang 
dirasakan untuk perilaku ini berubah. Perbedaan jenis kelamin juga diamati, karena wanita menganggap strategi pasif dan interaktif lebih normatif daripada pria selama tahap hubungan tertentu. Penelitian lainnya dari Jesse Fox, PhD, and Katie M. Warber, PhD (2014), Social Networking Sites in Romantic Relationships: Attachment, Uncertainty, and Partner Surveillanceon Facebook, penelitian ini menunjukkan sebuah hubungan yang tingkat ketidakpastian tertinggi. Sebelum munculnya media sosial, mungkin sulit untuk mengumpulkan informasi tentang mantan pasangan. Sekarang, mantan sibuk dan ketakutan mempertahankan akses ke kehidupan mantan pasangan mereka. Menjaga hubungan virtual ini dengan mantan seseorang dapat meningkatkan perasaan ketidakpastian tentang masa depan hubungan yang, tanpa media sosial, mungkin memiliki lebih jelas tentang kelanjutan hubungan tertentu.

Setelah mempelajari penelitian-penelitian terdahulu, maka pertanyaan penelitan yang muncul ialah bagaimanakah penggunaan media sosial Facebook bagi remaja laki-laki dalam menjalin hubungan pacaran?

\section{METODE PENELITIAN}

Metode penelitian adalah teknik di mana seorang spesialis mengumpulkan, mengelompokkan, dan menyelidiki realitas terkini di wilayah pemeriksaan dengan menggunakan sebagian informasi. Hal ini dilakukan untuk memutuskan suatu fakta (Hamidi, 1994). Teknik yang digunakan dalam penelitian ini adalah metode kualitatif karena peneliti perlu menjelaskan sistem yang digunakan oleh orangorang untuk mengurangi kerentanan dalam menjalin hubungan sentimental dengan rekannya melalui Facebook. Penelitian kualitatif menurut (Moleong, 2015) adalah strategi eksplorasi yang menghasilkan informasi ilustratif sebagai kata-kata yang disusun atau diungkapkan dari individu atau perilaku yang dapat dilihat. Eksplorasi semacam ini adalah studi literatur. Studi literatur merupakan rangkaian latihan yang diidentifikasikan dengan strategi pengumpulan informasi perpustakaan, membaca dan mencatat, serta mengawasi materi penelitian (Zed, 2008). Eksplorasi ini mengambil sumber dari buku harian dan semua referensi pendukung untuk kebutuhan penelitian. Sumber yang diambil adalah sumber yang diidentifikasi dengan metodologi yang digunakan oleh orang-orang untuk mengurangi 
ketidakpastian dalam membangun hubungan romantis dengan pasangan mereka melalui Facebook.

Dalam studi ini penulis mengarahkan wawancara di dalam dan luar untuk mengumpulkan informasi penting dari para informan. Menurut Kriyantono (2012) wawancara di dalam dan di luar merupakan metode pengumpulan informasi dan data secara langsung bertatap muka dengan sumber untuk mendapatkan informasi total dan dari atas ke bawah. Wawancara yang dilakukan adalah pertemuan semiterorganisir, dimana penulis telah berbicara dengan aturan sehingga tidak jauh dari percakapan, namun pertanyaan-pertanyaan yang ada saat ini dapat tercipta sesuai dengan kebutuhan (Moleong, 2015). Kemudian informasi tambahan yang didapat penulis dari data sekunder sebagai buku tulis yang membantu tema eksplorasi dan kajian masa lalu pada subjek serupa sehingga sangat baik dapat digunakan sebagai bahan referensi yang direkam sebagai hard copy eksplorasi ini. Selain pertimbangan penulisan, para analis juga mengarahkan catatan-catatan, khususnya pencarian informasi tentang masalah-masalah, seperti catatan, notulen, dll (Hadi, 1987).

\section{a. Informan Penelitian}

Teknik sampling purposive digunakan untuk memilih informan dalam penelitian ini. Teknik sampling purposive yaitu cara menentukan informan dengan memilih informan sesuai dengan kebutuhan dan kriteria studi ini.

Para remaja laki-laki yang terpilih adalah remaja laki-laki yang sedang menempuh studi Strata 1 di Universitas:

1. Am, menempuh studi di bidang Manajemen.

2. Dh, menempuh studi di bidang Akuntansi

\section{HASIL DAN PEMBAHASAN}

\section{a. Ketidakpastian dalam Hubungan Romantis}

Meskipun awalnya dikembangkan untuk interaksi awal, para sarjana juga mengandalkan URT untuk menjelaskan ketidakpastian dalam hubungan jangka panjang (Planalp \& Honeycutt, 1985; Planalp, Rutherford, \& Honeycutt, 1988). URT menyarankan bahwa ketika seseorang tidak dapat memprediksi atau menjelaskan perilaku seseorang, dia mengalami ketidakpastian; teori berpendapat bahwa ini tidak nyaman, yang memotivasi perilaku pengurangan ketidakpastian 
(Berger \& Calabrese, 1975). Berger (1979) mengidentifikasi tiga cara yang memungkinkan seseorang dapat mengurangi ketidakpastian, dua di antaranya terkait dengan studi ini. Cara pertama adalah strategi pasif, yang melibatkan pengawasan diam-diam dari pasangan. Kedua, strategi interaktif, yang melibatkan interaksi langsung dengan target ketidakpastian, yang secara konseptual mirip dengan keterbukaan. Memang, penelitian menunjukkan bahwa ketidakpastian adalah prediktor kuat dari penggunaan perilaku pemeliharaan hubungan prososial, menunjukkan itu sebagai salah satu cara pasangan romantis dapat mengurangi ketidakpastian (Dainton, 2003, 2011; Dainton \& Aylor, 2001).

Hubungan antara ketidakpastian dan penggunaan situs jejaring sangat kompleks. Di satu sisi, menggunakan situs jejaring sosial menyediakan jalan keluar untuk komunikasi pasangan dan tampilan publik dari hubungan tersebut yang mungkin mengurangi ketidakpastian. Sebaliknya, ambiguitas interaksi online dapat menyebabkan salah tafsir perilaku online oleh pasangan romantis. Misalnya, Facebook mungkin meningkatkan ketidakpastian pasangan karena hubungan signifikan yang ditemukan antara peningkatan penggunaan Facebook dan kecemburuan terkait Facebook. Proposisi ini konsisten dengan penelitian manajemen ketidakpastian oleh Brashers (2001), yang mengemukakan bahwa komunikasi dapat menjadi sumber dan mekanisme untuk menyelesaikan ketidakpastian. Perlu dicatat bahwa tidak semua ketidakpastian itu sama. Ada empat jenis ketidakpastian relasional: ketidakpastian perilaku, timbal balik, masa depan, dan definisi. Ketidakpastian perilaku mengacu pada batasan antara apa yang dianggap dapat diterima dan standar perilaku yang tidak dapat diterima dalam hubungan.

Ketidakpastian kebersamaan adalah apa yang dialami tentang kesamaan dan timbal balik perasaan bersama di antara pasangan. Ketidakpastian masa depan berkaitan dengan ramalan relasional jangka panjang dan hasil hubungan dari waktu ke waktu. Ketidakpastian definisi melibatkan bagaimana status hubungan dijelaskan oleh pasangan kepada orang-orang di luar hubungan. Penelitian sebelumnya telah menetapkan bahwa ketidakpastian relasional memprediksi berlakunya pemeliharaan prososial, terutama untuk pasangan yang berpacaran (Dainton, 2011). Misalnya, Dainton (2003) menemukan bahwa keempat bentuk 
ketidakpastian berkorelasi kuat dan negatif dengan jaminan, dan berkorelasi sedang, negatif dengan sisa enam perilaku pemeliharaan prososial. Dalam studi terpisah, Dainton (2011) menemukan bahwa ketidakpastian mutualitas adalah prediktor negatif dari penggunaan jaminan. Satu hal dipertanyakan adalah sifat hubungan antara mengalami ketidakpastian dan penggunaan perilaku pemeliharaan hubungan melalui Facebook. Kami mengusulkan bahwa perilaku pemantauan online dikaitkan dengan peningkatan tingkat ketidakpastian relasional (Muise et al., 2009), tetapi pemberlakuan pemeliharaan prososial di Facebook akan dikaitkan dengan penurunan tingkat ketidakpastian relasional (Dainton, 2003). Dengan demikian, dan seperti yang disarankan oleh URT, perilaku pemeliharaan dapat berfungsi baik untuk memicu dan mengurangi perasaan ketidakpastian.

\section{b. Penggunaan Facebook bagi Remaja Laki-Laki dalam Menjalin Hubungan Pacaran}

Penelitian ini menemukan bahwa media berbasis web Facebook memiliki bagian dalam elemen koneksi kencan, dari fase arahan hingga fase pertukaran yang stabil. Di setiap fase hubungan, media online Facebook memiliki pekerjaan alternatif. Pada fase arahan, Facebook dimanfaatkan oleh setiap sumber sebagai mekanisme korespondensi, di mana mereka menginvestasikan lebih banyak energi untuk bekerja sama melalui Facebook sebagai pengganti korespondensi bertatap muka. Kemudian dengan kompleksitas media berbasis web yang dapat menyimpan data individu, dimanfaatkan untuk mencari data yang dapat diidentifikasi dengan kemungkinan pasangannya. Adanya sensasi menikmati atau ketertarikan pada orang lain tidak langsung terjadi pada awal pertemuan, selama jangka waktu penelitian mereka juga melihat bahwa ada lebih banyak pendapatan pada calon pasangan mereka. Mereka melakukan ini dengan mentransfer foto terbaik atau rekaman individu (video), berkomunikasi melalui komentar, dan mengatur suka pada posting pasangan atau catatan resmi sehubungan dengan hubungan yang menghargai.

Pada fase selanjutnya hubungan, setiap pertemuan mengetahui karakter pasangan yang diharapkan. Karakter ini berasal dari korespondensi dan aktivitas online di Facebook. Dari gerakan online ini, setiap pertemuan juga bisa memberikan evaluasi calon paangan mereka tergantung dari unggahan yang mereka 
posting dan kekerabatan online mereka. Dengan begitu, mereka bisa memutuskan kelanjutan hubungan mereka.

Fase berikutnya adalah fase pertukaran penuh perasaan, di mana hubungan mereka telah memasuki awal pacaran. Pada fase ini, Facebook tidak dapat dipisahkan dari tugasnya sebagai wahana penyebaran data. Motivasi di balik penyebaran data ini adalah distribusi status hubungan, di mana mereka memberitahu publik bahwa status hubungan telah berubah dari tunggal menjadi dalam suatu hubungan. Mereka melakukan ini dengan mengunggah foto, rekaman, dan cerita bersama dengan perasaan romantis dan emoji yang mengungkapkan emosi mereka. Mereka melakukan ini sebagai jenis pemujaan, rasa syukur atau pengakuan, kepercayaan, penerimaan, dan membentengi pasangan dari orang lain.

Fase akhir adalah pertukaran stabil, di mana ada tingkat penerimaan yang tinggi untuk memeriksa semua bagian kehidupan dan pada tahap ini juga ada bahaya dan masalah kedekatan yang bisa diakhiri. Di puncak hubungan ini, pasangan tersedia satu sama lain dan transparansi mereka dengan pasangan mereka tidak lepas dari media berbasis web Facebook. Transparansi menyiratkan pertukaran kata sandi media online. Pertukaran kata sandi tidak hanya diartikan sebagai jenis penerimaan, tetapi juga kepercayaan dan penurunan kerentanan. Dengan pertukaran kata sandi, mudah bagi pasangan untuk melakukan pengawasan aktivitas online pasangan mereka.

\section{KESIMPULAN DAN SARAN}

Hasil penelitian ini menunjukkan bahwa URT merupakan kerangka teoritis yang tepat untuk memahami peran Facebook dalam hubungan asmara remaja. Hasil kami menunjukkan bahwa pengurangan ketidakpastian aktif dikaitkan dengan strategi pengurangan ketidakpastian pasif dalam hubungan romantis seperti pemantauan online, ini sepenuhnya sesuai dengan rumusan asli URT (Berger \& Calabrese, 1975). Sebaliknya, kurangnya ketidakpastian (terutama kepercayaan dalam definisi dan masa depan hubungan) dikaitkan dengan perilaku hubungan prososial, konsisten dengan aksioma URT yang menunjukkan bahwa peningkatan kepastian dikaitkan dengan peningkatan pengungkapan diri, keterkaitan, dan keintiman. Pasangan kencan yang mengandalkan situs jejaring sosial seperti 
Facebook harus tahu bahwa perilaku online mereka secara bersamaan dapat memicu dan menyelesaikan hasil hubungan negatif seperti ketidakpastian, kecemburuan, dan ketidakpuasan.

Media berbasis web Facebook dimanfaatkan sebagai fasilitator untuk peningkatan hubungan selama kurun waktu investigasi, dimana gagasan media berbasis web adalah korespondensi dan keterhubungan dua arah. Dengan ide media online, ia bisa menggantikan pertemuan tatap muka menjalin koneksi tanpa halangan tempat atau waktu. Selain itu, media online Facebook sebagai media perantara untuk menyampaikan pesan kepada calon pasangan tanpa hambatan, terutama untuk menyampaikan rasa hormat kepada calon pasangan.

Facebook bisa digunakan sebagai indikasi kewajiban terhadap suatu hubungan. Cepatnya penyebaran data melalui media online membuat pasangan yang berpacaran memanfaatkannya untuk menyatakan status hubungan mereka kepada orang-orang pada umumnya. Membagikan status hubungan melalui media online dimanfaatkan untuk membentengi pasangan dari orang lain. Mentransfer foto dengan seorang pasangan juga diharapkan sebagai bentuk penerimaan, perasaan bangga, dan pengakuan terhadap pasangannya. Kemudian lagi, Facebook dimanfaatkan sebagai sajian kehangatan publik, yang diakhiri oleh pasangan yang berpacaran untuk menunjukkan rasa cinta kepada pasangan dan sekaligus menunjukkan kondisi hubungan yang mereka jalani.

Adapun saran yang dapat diberikan dari hasil studi ini ialah diharapkan dapat menambahkan ilmu pengetahuan serta ketajaman analisis teori komunikasi dan penggunaan media sosial bagi remaja laki laki dalam menjalin hubungan pacaran ditinjau dari teori pengurangan ketidakpastian. Penelitian di masa depan harus berusaha untuk menguraikan karakteristik kepribadian seperti sifat kecemburuan pada pasangan dengan pengalaman situasional seperti kecemburuan di media sosial Facebook, serta perilaku seperti pemantauan online yang dapat berkontribusi dan menyelesaikan perasaan cemburu. Penelitian selanjutnya diharapkan menjabarkan untuk mengungkap kemungkinan atau kombinasi kemungkinan mana yang dapat menjelaskan sifat kecemburuan pasangan. 


\section{DAFTAR PUSTAKA}

Berger, C. R., \& Calabrese, R. (1975). Some Explorations In Initial Interaction And Beyond: Toward A Developmental Theory Of Interpersonal Communication. Human Communication Research. doi:10.1111=j.1468-2958.1975.tb00258

Berger, C. R. (1979). Beyond Initial Interaction: Uncertainty, Understanding, And The Development Of Interpersonal Relationships. In H. Giles \& R. St. Clair (Eds.), Language and social psychology. Oxford: Blackwell Press.

Bevan, J. L. (2004). General Partner And Relational Uncertainty As Consequences Of Another Person's Jealousy Expression. Western Journal of Communication. doi: $10.1080=10570310409374796$

Blight, Michael G., Ruppel, Erin K., Jagiello, Kristy. (2019). "Using Facebook Lets Me Know What He is Doing:" Relational Uncertainty, Breakups, and Renewals in On-again/Off-again Relationships. Southern Communication Journal. doi:10.1080/1041794x.2019.1641836

Brashers, D. E. (2001). Communication and Uncertainty Management. Journal of Communication. doi:10.1111=j.1460-2466.2001.tb02892.x

Bryant, E., \& Marmo, J. (2009). Relational Maintenance Strategies On Facebook. Convention Paper Presented At The National Communication Association's Annual Convention, Chicago, IL.

Dainton, M. (2000). Maintenance Behaviors, Expectations, And Satisfaction: Linking The Comparison Level To Relational Maintenance. Journal of Social and Personal Relationships. doi:10.1177=0265407500176007

Dainton, M. (2003). Equity And Uncertainty In Relational Maintenance. Western Journal of Communication. doi:10.1080=10570310309374765

Dainton, M. (2011). Linking Theoretical Explanations For The Use Of Relationship Maintenance: Equity, Uncertainty, Attachment, And Reciprocity. Psychological Research Records.

Donath, J. S., \& Boyd, D. (2004). Public Displays Of Connection. BT Technology Journal. doi:10.1023=B:BTTJ.0000047585.06264.cc

Ellison, N. B., Steinfield, C., \& Lampe, C. (2007). The Benefits Of Facebook "Friends": Social Capital And College Students' Use Of Online Social Network Sites. Journal of Computer-Mediated Communication. doi: $10.1111=\mathrm{j} .1083-6101.2007 .00367$

Facebook.com. (2012). Newsroom: Key facts. Retrieved from www.Facebook.com/press.php

Fox, Jesse; Warber, Katie M. (2014). Social Networking Sites in Romantic Relationships: Attachment, Uncertainty, and Partner Surveillance on Facebook. Cyberpsychology, Behavior, and Social Networking. doi:10.1089/cyber.2012.0667

Hadi, Sutrisno. (1987). Metodologi Reseach. Jakarta: Rineka Cipta

Jesse Fox, PhD, and Courtney Anderegg, MA. (2014). Romantic Relationship Stages and Social Networking Sites:Uncertainty Reduction Strategiesand Perceived Relational Norms on Facebook. doi: 10.1089/cyber.2014.0232 
Malcolm R. Parks Mara. Adelman. (1983). Communication Networks And The Development Of Romantic Relationships An Expansion of Uncertainty Reduction Theory. doi:10.1111/j.1468-2958.1983.tb00004.x

Margaret C. Stewart, Marianne Dainton \& Alan K. Goodboy. (2014). Maintaining Relationships on Facebook: Associations with Uncertainty, Jealousy, and Satisfaction. Communication Reports. doi: 10.1080/08934215.2013.845675

Moleong, Lexy J. (2015). Metode Penelitian Kualitatif. Bandung: Remaja Rosdakarya

Muise, A., Christofides, E., \& Desmarais, S. (2009). More Information Than You Ever Wanted: Does Facebook Bring Out The Green-Eyed Monster Of Jealousy?. Cyber Psychology and Behavior. doi:10.1089=cpb.2008.0263

Kriyantono. (2012). Public Relations \& Crisis Management: Pendekatan Critical Public Relations Etnografi Kritis \& Kualitatif. Jakarta: Kencana

Parks, M. R., \& Adelman, M. B. (1983). Communication Networks And The Development Of Romantic Relationships: An Expansion Of Uncertainty Reduction Theory. Human Communication Research. doi:10.1111=j.14682958.1983.tb00004.x

Planalp, S., \& Honeycutt, J. M. (1985). Events That Increase Uncertainty In Personal Relationships. Human Communication Research. doi:10.1111=j.1468-2958.1985.tb00062.x

Planalp, S., Rutherford, D. K., \& Honeycutt, J. M. (1988). Events That Increase Uncertainty In Personal Relationships II: Replication And Extension. Human Communication Research. doi:1468-2958.1988.tb00166.x

Stafford, L., \& Canary, D. J. (1991). Maintenance Strategies And Romantic Relationship Type, Gender And Relational Characteristics. Journal of Social and Personal Relationships. doi:10.1177=0265407591082004

Spitzberg, B. H., \& Hoobler, G. (2002). Cyberstalking And The Technologies Of Interpersonal Terrorism. New Media \& Society. doi: 1 P10.1177=14614440222226271

Utz, S., \& Beukeboom, C. J. (2011). The Role Of Social Network Sites In Romantic Relationships: Effects On Jealousy And Relationship Happiness. Journal of Computer-Mediated Communication. doi: 10.1111=j.1083-6101.2011.01552.x

Walther, J. B. (1996). Computer-Mediated Communication Impersonal, Interpersonal, And Hyperpersonal Interaction. Communication Research. doi: $10.1177=009365096023001001$

Westerman, D. (2008). How Do People Really Seek Information About Others?: Information Seeking Across Internet And Traditional Communication Channels. Journal of Computer-Mediated Communication. doi:10.1111=j.1083-6101.2008.00418.x

Zed, Mestika. (2008). Metode Penelitian Kepustakaan. Jakarta: Yayasan Obor Indonesia. 